\title{
EVALUASI PROGRAM DIKLAT UNGGULAN PUSDIKLAT TENAGA TEKNIS PENDIDIKAN DAN KEAGAMAAN 2018
}

\author{
EVALUATION OF PRIORITY TRAINING PROGRAM \\ AT CENTER OF EDUCATION AND TRAINING 2018
}

\author{
Cut N. Ummu Athiyah \\ Pusdiklat Tenaga Teknis Pendidikan dan Keagamaan \\ email: cutathiya@yahoo.com
}

Naskah Diterima: 01 Maret 2019; Direvisi: 12 Maret 2019; Disetujui: 22 April 2019

\begin{abstract}
This article is based on research that aimed to evaluate the implementation one of Priority Training Program for Madrasa English teachers of Ministry of Religions Affair (MoRA) Indonesia in 2018. . The researched aspects are: (1) the context of the legal basis, the goals and objectives of the training program; (2) input, namely curriculum, the background of human resources (organizers, instructors, participants) and education and training facilities; (3) the process, namely the object of research, namely the media and methods used in training and learning activities, as well as the suitability of the implementation of training and schedules; (4) results, namely the quality and quantity of participants who have participated in the training.This study uses a descriptive evaluative research; Context, Input, Process, and Product model (CIPP). The research sample uses purposive sampling technique with affordable samples (trainers, committees, participants) of training. Data collection techniques are: tests, observations, document studies and interviews. The data analysis technique used by researcher is: data collection, data reduction, data presentation, and conclusion drawing. The results of the research on the implementation of the CIPP model in the Substantive Training Program of English Language National Examination at Center Education and Training, MoRA in the 2018 has been running well (systematic, planned, organized, and continuous).
\end{abstract}

Keywords: CIPP; Programme evaluation; Substantive technical training

\begin{abstract}
Abstrak
Artikel ini merupakan hasil riset yang ditujukan mengevaluasi pelaksanaan salah satu program unggulan Pusdiklat Tenaga Teknis Pendidikan dan Keagamaan RI yaitu Diklat Teknis Substantif Ujian Nasional (UN) Bahasa Inggris Madrasah Aliyah. Aspek yang dikaji meliputi: (1) konteks yaitu dasar hukum, tujuan dan sasaran program diklat;(2) masukan yaitu kurikulum, latar belakang sumber daya manusia (penyelenggara, pengajar, peserta) dan sarana prasarana diklat; (3) proses yaitu objek penelitian yaitu media dan metode yang digunakan dalam kegiatan pembelajaran diklat, serta kesesuaian pelaksanaan diklat dengan jadwal;(4) hasil yaitu kualitas dan kuantitas peserta yang telah mengikuti diklat. Penelitian ini adalah penelitian deskriptif evaluatif dengan model CIPP (Context, Input, Process, Product). Sampel penelitian ini menggunakan teknik purposive sampling dengan sampel terjangkau, terdiri atas unsur: panitia, widyaiswara/narasumber, dan peserta diklat. Teknik pengumpulan data yang digunakan pada riset ini menggunakan tes, observasi, studi dokumen dan wawancara. Teknik analisis data yang digunakan peneliti adalah analisis data model Miles and Huberman meliputi pengumpulan data, reduksi data, penyajian data, dan penarikan kesimpulan. Hasil penelitian penerapan model CIPP pada Implementasi program Diklat Teknis Substantif Ujian Nasional (UN) Bahasa Inggris Madrasah Aliyah Pusdiklat Tenaga Teknis Pendidikan dan Keagamaan pada tahun 2018 didapat kesimpulan bahwa pelaksanaanya telah berjalan dengan baik (sistematik, terencana, teratur, dan berkesinambungan).
\end{abstract}

Kata kunci: CIPP; Diklat teknis substantif; Evaluasi program 


\section{PENDAHULUAN}

Peningkatan kompetensi Aparatur Sipil Negara (ASN) merupakan bagian utama dari program reformasi birokrasi di seluruh kementerian termasuk Kementerian Agama Republik Indonesia. Hal ini sejalan dengan amanat Undang-Undang No. 5 Tahun 2014 tentang Aparatur Sipil Negara (ASN) yang menegaskan bahwa penyelenggaraan pendidikan dan pelatihan (diklat) merupakan upaya untuk meningkatkan kompetensi pegawai.

Sebagai konsekuensi logis atas posisi strategis fungsi tersebut, lembaga diklat dituntut untuk mampu melakukan langkah kreatif dan inovatif dalam rangka meningkatkan mutu penyelenggaraan diklat sehingga dapat memberikan layanan diklat secara optimal. Layanan diklat yang dilakukan secara optimal pada gilirannya akan dapat menghasilkan output berupa alumni diklat yang kompeten sesuai dengan standar kompetensi yang diperlukan oleh organisasi kementerian atau lembaga pada masa sekarang maupun masa depan.

Pusdiklat Tenaga Teknis Pendidikan dan Keagamaan. teknis pendidikan dan keagamaan dan 14 (empat belas) Balai Diklat Keagamaan merupakan pilar pokok peningkatan kualitas sumber daya manusia di Kementerian Agama Hal ini sesuai dengan Peraturan Menteri Agama (PMA) nomor 75 tahun 2015 bahwa tujuan diklat pada Kementerian Agama adalah: (1) meningkatkan pengetahuan, keahlian, keterampilan dan sikap pegawai untuk dapat melaksanakan tugas jabatan secara profesional yang dilandasi kepribadian dan kode etik pegawai sesuai dengan kebutuhan Kementerian Agama; (2) menciptakan aparatur yang mampu berperan sebagai pembaru dan perekat persatuan dan kesatuan bangsa; (3) memantapkan orientasi sikap dan semangat pengabdian yang berorientasi kepada pelayanan, pengayoman, dan pemberdayaan masyarakat; dan (4) menciptakan pegawai berkualitas, profesional, berintegritas, dan bertanggung jawab.

Dalam kenyataannya saat ini masih banyak persoalan yang menyebabkan diklat belum berjalan sesuai harapan yang telah ditetapkan tujuan seperti di atas. Permasalahan yang terjadi di dalam penyelenggaraan diklat berdasarkan wawancara peneliti dengan beberapa staf kepanitiaan diklat dan kepada peserta diklat pada diklat teknis di Pusdiklat Tenaga Teknis Pendidikan teridentifikasi faktor eksternal antara lain: (1) keterlambatan informasi yang diterima peserta untuk bisa mengikuti diklat sehingga pada saat diklat sudah berlangsung masih ada peserta yang belum hadir, (2) sistem database yang belum berjalan sempurna, sehingga keikutsertaan pegawai dalam diklat tidak merata dan terkesan diskriminatif di kantor wilayah kementerian agamanya, (3) tidak sinkronnya data pegawai yang akan didiklat yang dikirimkan oleh kantor wilayah Kementerian Agama provinsi dengan data yang ada di Pusdiklat Teknis Pendidikan dan Keagamaan.

Faktor internal diantaranya: kendala penyelenggaraan diklat dari dalam lembaga diklat, meliputi (1) Belum dilaksanakannya Analisis Kebutuhan Diklat (AKD) secara sistematis; (2) masih ada panitia yang belum pernah mengikuti Training of Comitee (ToC); (3) keterkaitan durasi (alokasi waktu) belajar dengan banyaknya materi yang harus diberikan; (4) tingkat kecocokan dan keterpakaian materi di tempat kerja peserta; (5) performansi (tampilan) tenaga pengajar atau widyaiswara; (6) kompetensi widyaiswara yang belum sesuai dengan mata diklat yang harus diajarkan; (7) Sarana dan prasarana pembelajaran yang tersedia belum sesuai standar (Athiyah, 2016:45-54).

Permasalahan utama dari penelitian ini adalah dikarenakan Diklat Teknis Substantif Ujian Nasional (UN) baik jenjang Madrasah Tsanawiyah maupun Madrasah Aliyah (MA) merupakan diklat unggulan yang baru pertamakali diselenggarakan oleh Pusdiklat Tenaga Teknis Pendidikan dan Keagamaan dan belum pernah dilakukan kajian atau penelitian dalam implementasinya di tahun 2018.

Dengan melihat berbagai permasalahan yang ada, menjadi dasar perlunya dilakukan evaluasi untuk melihat efektivitas penyelenggaraan diklat secara lebih mendalam. Penulis merasa perlu sebuah evaluasi yang lebih komprehensif sebagai basis dalam mengambil keputusan. Model evaluasi Context, Input, Process, dan Product (CIPP) merupakan model yang paling banyak dikenal dan diterapkan oleh para evaluator. Model 
CIPP ini yang akan digunakan untuk mengevaluasi program yang dapat mengukur berbagai komponen efektvitas ketercapaian tujuan dan sasaran diklat. (Stufflebeam, 2003). Melalui evaluasi ini, diharapkan dapat mengungkapkan kekurangan dan keberhasilan implementasi program Pusdiklat Tenaga Teknis Pendidikan dan Keagamaan maupun Balai Diklat Keagamaan secara keseluruhan berdasarkan standar kediklatan yang ditetapkan melalui Peraturan Kepala Badan Litbang dan Diklat Nomor 60 Tahun 2012 sebagai acuan dan pedoman pelaksanaan beserta perangkatperangkat yang dibutuhkan dalam penyelengaraan diklat di Pusdiklat Tenaga Teknis Pendidikan dan Keagamaan dan Balai Diklat Keagamaan.

Berdasarkan pada identifikasi permasalahan, maka rumusan masalah dari penelitian, yaitu bagaimana: (1) context (konteks); (2) B input (masukan); (3) process (proses); (4) product (hasil) pada pogram Diklat Teknis Substantif UN Bahasa Inggris MA Pusdiklat Tenaga Teknis Pendidikan dan Keagamaan tahun 2018. Hasil penelitian ini diharapkan dapat memberikan manfaat bagi Pusdiklat Tenaga Teknis Pendidikan dan Keagamaan, di-antaranya: (1) sebagai dasar untuk penyusunan regulasi dan kebijakan program diklat, khususnya diklat unggulan di Pusdiklat Tenaga Teknis Pendidikan dan Keagamaan; (2) bentuk pengendalian mutu diklat agar menghasilkan alumni diklat yang kompeten baik dari aspek sikap, pengetahuan, maupun keterampilannya; (3) Sebagai bahan pertimbangan untuk perbaikan dalam penyelenggaran diklat khususnya diklat unggulan di Pusdiklat Tenaga Teknis Pendidikan dan Keagamaan.

\section{Kerangka Konseptual}

Evaluasi merupakan salah satu sarana dalam meraih tujuan. Gronlund \& Linn (1990) mendefinisikan evaluasi sebagai proses sistematis mengumpulkan, menganalisis, dan menafsirkan informasi untuk menentukan sejauh mana siswa mencapai Tujuan instruksional. Pendapat lain (Safari, 2011) menyatakan bahwa evaluasi adalah kegiatan untuk mengetahui apakah suatu program telah berhasil dan efisien serta efektif atau tidak. Dari pendapat ahli tersebut diketahui bahwa evaluasi merupakan suatu proses mengumpulkan informasi, meng-analisis, dan menginterprestasikan informasi sehingga dapat dijadikan tolak ukur untuk memberikan gambaran suatu keberhasilan suatu program.

Kegunaan evaluasi program merupakan suatu proses mendeskripsikan data (informasi) tentang suatu program dan hasilnya untuk pengambilan keputusan. Hal ini sejalan dengan pendapat yang (menyatakan bahwa penelitian evaluasi merupakan suatu proses yang dilakukan dalam rangka menentukan kebijakan dengan terlebih dahulu mempertimbangkan nilai-nilai positif dan keuntungan suatu program, serta mempertimbangkan proses serta teknik yang telah digunakan untuk melakukan penelitian setiap kegiatan evaluasi biasanya dimaksudkan untuk mengembangkan kerangka berfikir dalam rangka pengambilan keputusan (Suharsimi Arikunto, 2005).

Ada bermacam-macam model yang digunakan untuk pemahaman tentang evaluasi. Model evaluasi telah dikembangkan oleh beberapa ahli untuk melaksanakan penilaian program. Menurut Kaufman \& Thomas (dikutip oleh Suharsimi Arikunto dan Cepi Safruddin Abdul Jabar, 2009), membedakan model evaluasi menjadi empat, yaitu (a) Goal Oriented Evaluation Model dikembangkan oleh Tyler; (b) Goal Free Evaluation Model dikembangkan oleh Scriven; (c) Formatif \& Summative Evaluation Model dikembangkan oleh Michael Scriven; (d) Countenance Evaluation Model dikembangkan oleh Stake.

Responsive Evaluation Model, dikembangkan oleh Stake. CSE-UCLA Evaluation Model menekankan pada "kapan" evaluasi dilakukan. CIPP Evaluation Model dikembangkan oleh Stufflebeam. Discrepancy Model dikembangkan oleh Provus. Dari berbagai model evaluasi program maka dalam pemilihan model evaluasi yang akan digunakan disesuaikan dengan tujuan evaluasi pada program yang dilaksanakan, yaitu evaluasi model CIPP.

Stufflebeam (dalam Roger Kaufman dan Susan Thomas, 1980) mengidentifikasikan empat tipe evaluasi yang didasarkan pada model CIPP. Evaluasi konteks berguna dalam tahap awal pengembangan program antara lain untuk mengidentifikasi kebutuhan dan 
perancangan dasar pemikiran pada program. Evaluasi masukan berguna dalam mengidentifikasi apa yang sebenarnya akan diperlukan untuk memenuhi tujuan yang telah ditetapkan dalam evaluasi konteks. Sedangkan, evaluasi proses memiliki banyak kesamaan dengan evaluasi formatif. Keduanya digunakan sementara program yang disampaikan dan berguna dalam menentukan apakah program ini yang disampaikan seperti yang awalnya direncanakan. Evaluasi hasil terjadi selama serta setelah program, dengan penekanan pada pengumpulan informasi yang diperlukan untuk keputusan yang harus dibuat mengenai program.

CIPP adalah kumpulan informasi yang terangkum secara sistematis mengenai aktivitas, karakteristik dan keluaran dari program yang digunakan oleh orang-orang tertentu untuk mengevaluasi dan mengurangi kegagalan, meningkatkan efektivitas dan membuat keputusan mengenai program yang akan dilaksanakan beserta dampak yang menyertainya. Untuk melayani para manajer dan administrator menghadapi empat macam keputusan pendidikan, CIPP dibagi menjadi empat macam.

Context evaluation to serve planning decision. Konteks evaluasi ini membantu merencanakan keputusan dalam menentukan kebutuhan yang akan dicapai oleh program dan merumuskan tujuan program (Stufflebeam, 2016). Input evaluation, structuring decision. Evaluasi ini membantu dalam mengatur keputusan, menentukan sumber-sumber yang ada, alternatif apa yang diambil, apa rencana dan strategi untuk mencapai kebutuhan. Evaluasi input dapat digunakan untuk merancang desain program yang akan dilaksanakan.

Process evaluation to serve implementing decision. Evaluasi proses untuk membantu mengimplementasikan kebutuhan dalam pembuatan keputusan. Penilain proses ini menunjuk pada kegiatan yang akan dilakukan dalam program. Product evaluation to serve recycling decesion. Evaluasi produk untuk menolong keputusan selanjutnya. Apa hasil yang telah dicapai? Apa yang dilakukan setelah program berjalan.
Penelitian evaluatif menggunakan model CIPP tidak bertujuan untuk melakukan pembuktian keberhasilan sebuah program namun lebih pada bagaimana menindaklanjutinya menjadi peningkatan efektifitas sebuah program. (George Madaus et. al, 1985).

Penelitian Eko Rachmat Suprabowo (2012) tentang evaluasi program pelatihan komputer di Balai Latihan Kerja Kabupaten Kulon Progo. Hasil penelitian ini mengarah pada evaluasi konteks, masukan, proses, dan hasil program pelatihan komputer. Dari hasil evaluasi program pelatihan dijelaskan bahwa program dapat dilanjutkan dengan beberapa pembenahan dan perbaikan guna menghasilkan pelayanan program pelatihan yang maksimal dan menghasilkan kualitas serta kuantitas lulusan yang benar-benar memiliki kompetensi dan profesional di bidang komputer.

Penelitian lain (Wahyu Tri Widodo, 2012) mengenai Evaluasi Program Pendidikan dan Pelatihan Operator Komputer di Balai Latihan Kerja Siraman Wonosari Kabupaten Gunung Kidul. Penelitiannya memberikan penjelasan mengenai gambaran tentang komponen dalam evaluasi yang selanjutnya dengan mencari persentase jawaban dari tiaptiap sub variabel. Hasil penelitian terhadap lima kategori penilaian yang meliputi keterlaksanaan kurikulum, kualitas proses belajar mengajar, kualitas kinerja pendidik, kualitas sarana prasarana, dan kualitas kinerja pengelola. Di sisi lain hasil penelitian menunjukan indikasi bahwa komunikasi bisa berjalan dua arah karena hampir semua peserta termotivasi untuk mengikuti program pendidikan dan pelatihan (Wahyu, 2012).

Evaluasi pada penelitian ini merupakan kegiatan pengumpulan data dan informasi untuk pengambilan keputusan mengenai program yang sedang berjalan, keputusan tersebut antara lain melanjutkan program, memperluas program, memperbaiki program, dan menghentikan program.

\section{METODOLOGI}

Jenis penelitian ini adalah penelitian deskriptif evaluatif. Penelitian deskriptif memberikan gambaran secara sistematis, faktual dan akurat sebuah fenomena atau hubungan antarfenomena yang diselidiki 
(Suprayogo, Tobroni, 2001: 136-137). Pendekatan yang digunakan dalam penelitian adalah pendekatan evaluatif, dimana peneliti bermaksud mengumpulkan data tentang implementasi kebijakan program diklat unggulan pada Pusdiklat Tenaga Teknis Pendidikan dan Keagamaan. Penelitian evaluatif berorientasi pada rekomendasi akhir yang menegaskan bahwa suatu objek evaluasi dapat dipertahankan, diperbaiki, ditingkatkan, atau bahkan diberhentikan sejalan dengan data dan kesimpulan yang diperoleh.

Untuk mengetahui hasil evaluasi program pendidikan dan pelatihan Teknis Substantif UN Bahasa Inggris MA Pusdiklat Tenaga Teknis Pendidikan dan Keagamaan tahun 2018 digunakan model evaluasi CIPP.

Penelitian ini bertempat di Kampus Pusdiklat Tenaga Teknis Pendidikan dan Keagamaan. Penelitian dilaksanakan mulai dari Mei sampai Desember 2018. Objek peneilitian ini adalah pelaksanaan Diklat Teknis Substantif UN Bahasa Inggris MA tahun 2018 sedangkan penelitian sebagai sumber data dalam penelitian ini adalah panitia, widyaiswara, dan peserta Kehadiran peneliti dalam program diklat ini juga sebagai widyaiswara untuk dua mata diklat.

Sampel penelitian menggunakan teknik purposive sampling dengan sampel terjangkau yaitu panitia, widyaiswara, dan peserta Diklat. Teknik pengumpulan data pada penelitian ini adalah observasi, wawancara, dokumentasi, dan tes. Dengan teknik pengumpulan data tersebut maka instrumen penelitian yang digunakan dalam penelitian ini adalah pedoman wawancara, pedoman observasi dan pedoman studi dokumentasi, dan tes. Kisi-kisi instrumen evaluasi diklat berisikan aspek, komponen, indikator, sub-indikator, sumber data, dan metode pengumpulan data.

Analisis data yang digunakan peneliti adalah analisis data model Miles dan Huberman meliputi pengumpulan data, reduksi data, penyajian data, dan penarikan kesimpulan (Sugiyono, 2013). Langkah analisis data yang peneliti lakukan: (a) pengumpulan data (data collection). Dalam penelitian ini pengumpulan data dilakukan melalui wawancara, observasi dan studi dokumentasi. Setelah data terkumpul disajikan dalam bentuk hasil wawancara, hasil studi dokumentasi dan deskripsi hasil pengamatan; (b) reduksi data (data reduction) reduksi data alam penelitian dimaksudkan untuk merangkum data yang telah dipilah yang berupa hal-hal yang pokok dan penting; (c) penyajian data (data display). Penyajian data merupakan hasil dari reduksi data, yang disajikan dalam bentuk laporan secara sistematis yang mudah dibaca atau dipahami baik secara keseluruhan maupun bagianbagiannya dalam konteks sebagai pernyataan. Penyajian data ini bisa berbentuk grafik, tabel, matrik atau bagan informasi; dan (d) penarikan kesimpulan (conclusion drawing/verification).

Langkah verifikasi merupakan upaya untuk mencari makna data yang dikumpulkan. Pada tahap ini peneliti mengambil kesimpulan terhadap data yang telah direduksi ke dalam laporan secara sistematis dengan cara membandingkan, menghubungkan, dan memilih data yang mengarah kepada pemecahan masalah. Langkah-langkah verifikasi data sebagai berikut: (1) Membandingkan antara hasil studi dokumenter dengan hasil informasi dari hasil wawancara ataupun observasi; (2) Mengidentifikasi data-data yang terkait dengan fokus penelitian; (3) Menarik simpulan serta saran-saran terhadap masalah yang telah diteliti.

\section{HASIL DAN PEMBAHASAN}

Hasil penelitian dan pembahasan disajikan mulai dari aspek konteks, aspek input (masukan), aspek proses, serta aspek hasil program Diklat Teknis Substantif UN Bahasa Inggris MA tahun 2018. Data diperoleh dari hasil tes, wawancara, observasi non partisipan dan studi dokumentasi. Hasil penelitian dipaparkan sebagai berikut ini.

\section{Hasil Aspek Konteks}

Dasar hukum program diklat ini antara lain Undang-Undang Nomor 20 Tahun 2003 tentang Sisdiknas, Undang-undang Nomor 5 Tahun 2014 tentang Aparatur Sipil Negara, Peraturan Pemerintah Nomor 101 Tahun 2004 tentang Pendidikan dan Pelatihan Jabatan Pegawai Negeri Sipil.

Peraturan Menteri Agama No. 75 Tahun 2015 tentang Penyelenggaraan Pendidikan dan Pelatihan Pegawai Pada Kementerian Agama 
dinyatakan bahwa Pusdiklat Tenaga Teknis Pendidikan dan Keagamaan mempunyai tugas menyelenggarakan Diklat Tenaga Teknis Pendidikan dan Keagamaan, Pengembangan Sistem Kediklatan Tenaga Teknis Pendidikan dan Keagamaan, Pengendalian Mutu Diklat dan Pembina Unit Pelaksanaan Teknis (UPT) di bidang pelaksanaan Diklat Tenaga Teknis Pendidikan dan Keagamaan.

Berdasarkan Surat Keputusan Kepala Badan Litbang dan Diklat Nomor 62 Tahun 2018, secara garis besar terdapat dua jenis diklat dalam Jabatan yang diselenggarakan oleh Pusdiklat Tenaga Teknis Pendidikan dan Keagamaan yaitu Diklat Fungsional dan Diklat Substantif. Diklat Fungsional merupakan diklat yang dilaksanakan untuk memenuhi kompetensi yang dipersyaratkan sesuai jabatan fungsional masing-masing yang diperlukan untuk pelaksanaan tugas jabatannya. Diklat substantif merupakan diklat yang diselengarakan untuk memberikan pengetahuan dan keterampilan yang bersifat substantif dalam rangka pencapaian kompetensi yang terkait dengan pekerjaan yang bersangkutan, sehingga mampu melaksanakan tugas dan tanggung jawabnya secara profesional.

Agar Diklat ini berjalan sesuai dengan fungsinya, maka ditetapkan tujuan dan sasarannya. Tujuan setelah mengikuti diklat ini, peserta diharapkan mampu meningkatkan kompetensi sehingga meningkatnya nilai UN di setiap MA. Sedangkan sasaran dari Diklat Teknis Substantif UN Mata Pelajaran Bahasa Inggris MA yaitu terdidik, terlatih, dan terampilnya guru mata pelajaran Bahasa Inggris MA agar peserta mampu meningkatkan hasil UN Bahasa Inggris di madrasahnya pada tahun mendatang (Panduan Diklat Teknis Substantif UN Mata Pelajaran Bahasa Inggris MA tahun 2018).

\section{Hasil Aspek Input}

Kurikulum yang digunakan untuk ini sesuai dengan materi pembelajaran yang diajarkan kepada peserta diklat. Hal ini diungkapkan dalam wawancara dengan EP sebagai peserta diklat dari Provinsi Bengkulu pada tanggal 3 Juli 2018, "kurikulumnya sudah sesuai karena ada pedomannya sebagai pertimbangan untuk materi mengajar tersebut.
Misalnya ada Rencana Tidak Lanjut (RTL) yang harus kita implementasi sepulang dari diklat sehingga sertifikat juga diserahkan kalau kita bisa membuktikan bila sudah melaksanakan RTL itu".

Pernyataan yang sama juga diungkapkan oleh $\mathrm{Rn}$. sebagai penyelenggara diklat pada wawancara tanggal 13 Juli 2018, "kurikulum yang kita gunakan mengacu pada peraturan kediklatan, sebagaimana tercantum dalam buku panduan diklat Diklat Teknis Substantif UN Mata Pelajaran Bahasa Inggris MA".

Struktur kurikulum diklat di Pusdiklat Tenaga Teknis Pendidikan dan Keagamaan tersusun lengkap dalam dokumen Lampiran kurikulum pada Surat Keputusan Kepala Badan Litbang dan Diklat Nomor 62 Tahun 2018. Struktur kurikulum tersebut berisi materi pelatihan serta jumlah jam pelatihan (JP) yang dikelompokkan menjadi 3 (tiga) bagian, yaitu materi dasar, materi inti, dan materi penunjang.

\section{Sumber Daya Manusia (Penyelenggara, Pengajar, dan Peserta)}

Sumber daya manusia yang terlibat dalam pelaksanaan diklat Teknis Substantif UN Mata Pelajaran Bahasa Inggris MA di Pusdiklat Tenaga Teknis Pendidikan dan Keagamaan antara lain Kepala Pusdiklat Tenaga Teknis Pendidikan dan Keagamaan, panitia penyelenggara, pengajar, dan peserta. Kapusdiklat menunjuk Kepala Bagian atau Kepala Bidang yang ada sebagai penanggung jawab teknis (panitia penyelenggara). Panitia penyelenggara berjumlah 4 orang yang dibantu oleh 3 orang petugas. Pengajar pada diklat ini berasal dari widyaiswara internal maupun pengajar eksternal.

Kualifikasi widyaiswara pada program diklat ini merujuk pada panduan diklat dan PerKa Badan Litbang Nomor 60 Tahun 2013. Tenaga Pengajar diklat adalah widyaiswara baik dari internal maupun dari eksternal Pusdiklat Tenaga Teknis Pendidikan dan Keagamaan yang mendapat tugas melaksanakan dikjartih pada suatu program diklat, yang memiliki: (1) ijazah serendahrendahnya S1 yang sesuai dengan spesialisasinya dari perguruan tinggi terakreditasi dan atau; (2) memiliki sertifikat Training of Trainer (ToT) yang sesuai dengan 
spesialisasi; (3) berpengalaman melaksanakan fungsi sebagai pejabat yang sesuai dengan program diklat; dan (4) memiliki spesialisasi yang relevan dengan mata diklat yang diampu pada program Diklat Tenaga Teknis.

Hal penting yang menjadi catatan lain pada penelitian ini adalah widyaiswara internal (Kementerian Agama) pengampu mata diklat inti harus lulus ToT bagi Widyaiswara Spesialisasi Bahasa Inggris yang diselenggarakan oleh Pusdiklat Tenaga Teknis Pendidikan dan Keagamaan. Peneliti sebagai salah satu pengampu mata diklat inti pada diklat ini juga telah bersertifikat ToT Widyaiswara Bahasa Inggris.

Target peserta Diklat Teknis Substantif UN Mata Pelajaran Bahasa Inggris MA Tahun 2018 yang tertera dalam dokumen, keseluruhan berjumlah 34 orang yang mewakili 34 provinsi. Peserta diklat merupakan para ASN di lingkungan Kementerian Agama. Hal ini sesuai yang diungkapkan M.Tm. sebagai Penanggung jawab Diklat Teknis Substantif UN Bahasa Inggris MA pada wawancara tanggal 4 Juli 2018, "Biasanya diklat perangkatan itu 30 orang, namun khusus diklat unggulan ini dikarenakan sangat dibutuhkan maka diwakili satu orang setiap provinsi".

Berdasarkan hasil dokumentasi, peserta pendidikan dan pelatihan ini adalah Guru Mata Pelajaran Bahasa Inggris MA yang berasal dari MAN di 34 provinsi seluruh Indonesia. Untuk peserta yang berasal dari MA ada persyaratan yang berbeda yaitu peserta berasal dari guru kelas XII.

Sarana prasarana untuk diklat yang ada di Pusdiklat Tenaga Teknis Pendidikan dan Keagamaan cukup lengkap dan baik. Panitia menyediakan beberapa fasilitas di lingkungan kampus/asrama Pusdiklat Tenaga Teknis Pendidikan dan Keagamaan sebagai berikut: Mushola di Gedung III Lantai 1, Perpustakaan di Gedung I Lantai 1, Laboratoruim Bahasa dan Komputer di Gedung II Lantai 2, Sarana Olah Raga Lapangan Bulu tangkis di Gedung II Lantai 5, HotSpot untuk mengakses Internet melalui nirkabel/wireless.

Fasilitas pembelajaran untuk kebutuhan diklat seperti meja, kursi, gedung asrama, laptop, LCD, papan tulis, kertas untuk simulasi sudah sangat mencukupi. Seperti yang diungkapkan oleh MK sebagai pengajar diklat UN Bahasa Inggris pada wawancara tanggal 25 Juli 2018, "Cukup kalau di Pusdiklat Tenaga Teknis Pendidikan dan Keagamaan, memang secara umum standar sarana prasana untuk kelas dan fasilitas mengajarnya sudah memadai. Untuk fasilitas pembelajaran seperti meja, kursi, gedung juga bagus, namun mungkin karena jumlah peserta 34 orang posisi duduknya agak rapat, lalu agak kurang nyaman untuk diskusi kelompok".

Sesuai hasil observasi atau pengamatan dari sekian banyaknya sarana prasarana yang ada di Pusdiklat Tenaga Teknis Pendidikan dan Keagamaan kondisi sarana prasarana dalam keadaaan baik meskipun ada beberapa item yang kondisinya perlu diperhatikan seperti LCD proyektor yang agak buram, sound system yang terkadang kurang lancar, dan tata letak kursi dan meja yang kurang sesuai untuk model pembelajaran interaktif. Untuk ruang asrama sangat memadai. Demikian pula fasilitas ruang makan yang sangat baik, hanya gelas dan piring yang disediakan pihak katering pemenang tender seringkali ditemukan retak atau sudah kusam.

\section{Hasil Aspek Proses}

Penetapan peserta, pembahasan distribusi dan penjadwalan tugas panitia dan penetapan keputusan kepantiaan telah terlaksana sesuai ketentuan. SK Kepanitiaan dan kepesertaan Diklat Bahasa Inggris UN MA diterbitkan 4 hari sebelum hari pelaksanaan, diklat yaitu 18 Juli 2018.

Pengaturan jadwal diklat sudah dipersiapkan jauh hari yang dirapatkan melalui kegiatan Rapat di Kantor (RDK). Diklat dilaksanakan selama 10 (sepuluh) hari kerja. Pemberian materi diklat yang disampaikan widyaiswara itu sesuai yang sudah terjadwal dan tidak mengalami perubahan.

\section{Pelaksanaan Pembelajaran (media, pendekatan, metode)}

Berdasarkan laporan penyelenggaran Diklat Teknis Substantif UN Mata Pelajaran Bahasa Inggris MA Tahun 2018 media prasarana (media pembelajaran) yang digunakan dalam diklat ini antara lain LCD 
dan laptop, sound system/wireless mic, white board dan spidol whiteboard marker, dan kertas plano. Jadi setiap pertemuan peserta diberikan soft copy, berisi power point, dan lembar kerja dari seluruh narasumber.

Para widyaiswara/pengajar pada diklat UN Bahasa Inggris MA telah maksimal dalam menggunakan media pembelajaran tersebut, disamping itu mereka sudah sesuai dengan kompetensinya dan orang-orang yang memiliki pengalaman tentang UN mata pelajaran Bahasa Inggris, seperti yang diungkapkan salah seorang peserta Diklat UN Bahasa Inggris MA pada wawancara tanggal 28 Juli 2018, "Kalau menurut saya pribadi sudah cukup puas dengan pengajarnya, jadi mereka itu orangorang yang memiliki pengalaman tentang proses penyusunan soal UN Bahasa Inggris. Ilmunya ada, kalau ditanya itu bisa jawab dan penjelasannya itu gamblang/jelas seperti kasus real di lapangan itu bagaimana dan mereka bisa karena mereka tidak hanya baca, tapi mereka di dalamnya sendiri dan mereka pernah mengalami itu pernah jadi tim penulis soal UN di Puskur Kemendikbud juga ada".

Pendekatan Pembelajaran yang disampaikan oleh widyaiswara sebagian besar telah menggunakan pendekatan pembelajaran orang dewasa/andragogy, namun peneliti masih melihat ada narasumber yang juga masih dominan dalam proses dan kurang menggali potensi peserta diklat. Metode pembelajaran selama kegiatan diklat di kampus yang digunakan oleh pengajar dalam pengamatan peneliti sudah beragam, mulai dari ceramah, jawab, latihan soal, dan simulasi, kerja kelompok termasuk diskusi dan presentasi. Bahan ajar, lembar kerja, dan bahan tayang/ power point juga disiapkan oleh widyaiswara. Dalam wawancara dengan Fn salah seorang peserta yang berasal dari Kab. Lombok, menyatakan "Saya sangat senang saat diajarkan pembuatan materi listening dengan software dari widyaiswara. Hanya saja waktunya sangat kurang, jadi belum maksimal hasilnya. Kami uji coba langsung saat malam hari, untuk soal listening tidak terasa sampai pukul 12 malam, tapi kami sangat senang. Juga saat materi rencana praktik, mengenai tips mencari jawaban yang tepat dan cepat itu bagus sekali”.
Bahan dari materi yang disampaikan disesuaikan dengan kurikulum dan indikator yang telah ditentukan oleh panitia pada saat undangan permohonan mengajar dikirimkan pada semua widyaiswara, baik internal maupun eksternal. Hal ini seperti yang diungkapkan GUS Sebagai Pengajar diklat pada wawancara tanggal 26 Juni 2018,: "Kami pasti pakai metode ceramah, karena materi konsep dasar harus tersampaikan. Lalu diskusi selalu dikebangkan untuk mengetahui respon peserta bagaimana tanggapan mereka terhadap diri kita. Lalu ada simulasi berupa ceramah, diskusi, dan simulasi, jadi bagaimana cara praktek analisis SKL KI, KD, dan kisi-kisi soal UN Bahasa Inggris MA"

Peneliti sendiri juga mengisi materi dengan mengombinasikan ceramah, brain stroming, diskusi kelompok, dan praktek simulasi pada sesi pelatihan secara bervariasi. Sesi awal menyampaikan materi menyampaikan konsep dasar sekitar 45 menit, lalu dikembangkan dengan diskusi, simulasi, praktik, dan presentasi.

Diakhir materi peserta diminta berpartisipasi aktif dengan simulasi. Widyaiswara membagikan soal, lalu dibuat studi kasus dan dibentuk kelompok. Jumlah kelompok berkisar antara 5 sampai dengan 10 orang dan untuk masing-masing kelompok berbeda kasus. Soal-soal telah dipersiapkan pengajar dalam bentuk hardcopy. Selama mengerjakan soal, pengajar mendampingi peserta dalam menjawab, berdiskusi, sampai peserta presentasi. Setiap kelompok akan berdiskusi mengerjakan secara kelompok lalu mereka akan menunjuk juru bicara atau presentator dan pengajar akan menilai.

Peneliti memberi kebebasan untuk mengerjakan soal di ruangan kelas dengan kelompoknya. Untuk bentuk simulasi peserta diminta mempraktikkan langkah-langkah pemecahan soal UN mata pelajaran Bahasa Inggris di depan peserta didik (diwakili anggota kelompok) dan peserta lain diminta menanggapi. Di akhir sesi peneliti melakukan penguatan dan memberikan komentar terhadap apa yang sudah disimulasikan oleh peserta diklat.

Untuk melihat kompetensi keterampilan peserta diklat pada mata diklat Praktik 
Penyelesaian Soal UN Bahasa Inggris MA, dilaksanakan kegiatan praktik lapangan yang bertempat di MAN 2 Bogor. Peneliti langsung bertindak sebagai pembimbing kegiatan ini. Peneliti melakukan observasi dan melihat peserta diklat telah mampu melakukan pembimbingan pada peserta didik di sana untuk melakukan penyelesaian soal-soal bernuansa Higher Order Thinking Skill (HOTS) dengan baik dan interaktif. Pertama siswa kelas XII diminta mengerjakan 3 paket soal yang telah disusun oleh peserta diklat (selama proses diklat). Setelah mengerjakan soal-soal tersebut siswa diminta mengungkapkan kesulitan yang mereka hadapi dalam mengerjakan soal-soal tersebut. Kemudian secara bergantian peserta membimbing dan memberikan beberapa trik atau clue dalam mengerjakan soal, agar memperoleh jawaban secara cepat dan tepat.

\section{Hasil Aspek Produk}

Hasil akhir peserta diklat, 34 (tiga puluh empat) orang dinyatakan lulus untuk tes Seperti yang diungkapkan Tm sebagai Penyelenggara Diklat UN Bahasa Inggris MA pada wawancara tanggal 1 Agustus 2018, "Dari hasil pengolahan nilai keseluruhan peserta tingkat ketercapaian diklat ini sudah memenuhi target. Semua peserta lulus, hal ini sesuai dengan pedoman kelulusan yang ada di Pusdiklat Tenaga Teknis Pendidikan dan Keagamaan". Evaluasi kuantitas Peserta diklat ditentukan dari jumlah peserta yang dinyatakan lulus. Nilai Akhir (NA) peserta merupakan nilai akumulatif dari hasil penilaian terhadap aspek sikap (NS), pengetahuan dan keterampilan (NP), dan RTL dengan bobot yaitu NS 30\%, NP 30\%, dan RTL $40 \%$. Peserta yang mendapatkan NA minimal 76 berhak mendapatkan Sertifikat Pelatihan dengan kriteria "LULUS" dan predikat: Sangat Kompeten $(92,00 \leq \mathrm{NA} \leq 100)$; Kompeten (84,00 $\leq \mathrm{NA}<92,00)$; Cukup Kompeten $(76,00$ $\leq$ NA <84,00); dan Kurang Kompeten (NA $<76,00)$. Evaluasi terhadap kualitas peserta diklat akan dilaksanakan melalui penilaian terhadap aspek sikap, pengetahuan, keterampilan, dan pelaksanaan RTL. Pelaksanaan evaluasi meliputi: (1) sikap peserta terkait indikator aspek kehadiran, berpakaian, keaktifan, penyelesaian tugas, solutif, komitmen, dan perilaku selama mengikuti diklat maupun setelah melaksanakan implementasi RTL saat kembali ke tempat tugas; (2) Penilaian pengetahuan menggunakan pre dan post test serta penugasan; dan (3) penilaian keterampilan melalui penilaian kinerja, baik proses maupun produk serta penilaian terhadap pelaksanaan RTL. Dari 34 orang peserta Diklat UN Bahasa Inggris MA 1 orang memperoleh nilai cukup kompeten dan 33 orang memperoleh nilai kompeten. Nilai tertinggi adalah 80,75 sedangkan nilai terendah adalah 72,85. Kualitas peserta yang telah mengikuti diklat dapat dilihat dari nilai test pengetahuan maupun keterampilan yang dilakukan oleh peneliti sebagai pengajar pada diklat ini karena Diklat UN Bahasa Inggris MA ini adalah diklat unggulan, maka perlu betul-betul dicermati produk/output.

Berkaitan dengan kualitas peserta diklat, dapat ditinjau dari aspek pengetahuan yang dilakukan dengan pengukuran melalui pre dan post test. Tes pengetahuan berbentuk pilihan ganda sejumlah 35 butir soal. Soal tersebut adalah soal yang dibuat oleh peserta workshop penyusunan soal UN MAN IC se-Indonesia di MAN IC Serpong tahun 2018 yang telah dilakukan validasi oleh tim dari Puskur Kemendikbud sehingga peneliti tidak melakukan uji homogenitas dan reliabilitas pada soal tersebut. Nilai rata-rata pada pre test peserta diklat adalah 74,24 sedangkan nilai rata-rata post test 82,15 . Hasil pre-post test tersebut dapat dilihat pada Gambar 1.

Dari uji $t$ dengan menggunakan Software Statistical Packages for Social Science (SPSS) for Window Release 17,00 diperoleh nilai $t=$ $\mathbf{6 , 4 1 3}$ dengan $d f=33$, dan nilai p-value $=0,000$ artinya $\mid \mathrm{t}$ hitung $\mid>t$ tabel atau $\mid \mathrm{t}-6413$ $\mid>2,035$ jadi Ho $\left(\mu_{1}=\mu_{2}\right)$ ditolak dan Ha $\left(\mu_{1} \neq\right.$ $\left.\mu_{2}\right)$ diterima. Dengan demikian dapat disimpulkan bahwa ada peningkatan yang signifikan pengetahuan peserta diklat setelah mengikuti diklat sebesar rata-rata 7,91. Artinya diklat telah berjalan efektif sesuai dengan tujuan yang telah ditetapkan yaitu terjadi peningkatan pengetahuan peserta (Tabel 1).

Untuk mengetahui tingkat keberhasilan aspek keterampilan maka dilaksanakan RTL. Peneliti melakukan pengecekan keterlaksanaan RTL. Peneliti berhasil memperoleh informasi 
implementasi RTL pada beberapa wilayah, diantaranya kegiatan RTL berupa diseminasi yang dilakukan oleh beberapa orang peserta diklat. Peserta memiliki kemampuan maupun motivasi untuk menindaklanjuti pengetahuan maupun keterampilan baru yang mereka peroleh selama mengikuti diklat teknis substantif UN Bahasa Inggris MA.

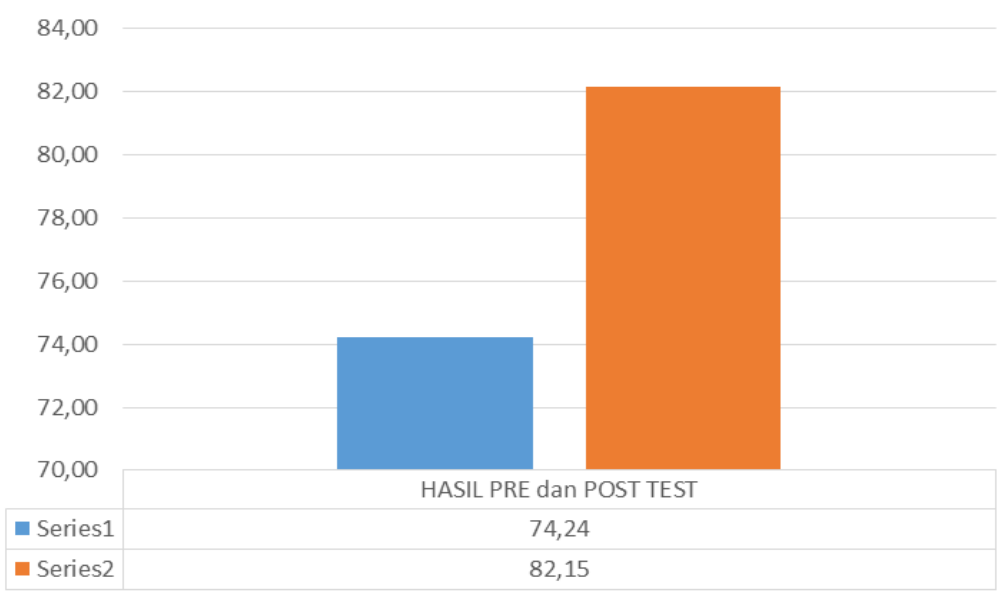

Gambar 1. Hasil nilai rata-rata pre-post test peserta diklat

Tabel 1. Hasil uji t pada pre dan post test peserta diklat

\begin{tabular}{|c|c|c|c|c|c|c|c|c|}
\hline & \multicolumn{5}{|c|}{ Paired Differences } & \multirow[t]{3}{*}{$\mathrm{T}$} & \multirow[t]{3}{*}{ df } & \multirow{3}{*}{$\begin{array}{l}\text { Sig. } \\
\text { (2- } \\
\text { taile } \\
\text { d) }\end{array}$} \\
\hline & \multirow[t]{2}{*}{ Mean } & \multirow[t]{2}{*}{$\begin{array}{c}\text { Std. } \\
\text { Deviati } \\
\text { on }\end{array}$} & \multirow[t]{2}{*}{$\begin{array}{l}\text { Std. } \\
\text { Error } \\
\text { Mean }\end{array}$} & \multicolumn{2}{|c|}{$\begin{array}{c}95 \% \text { Confidence } \\
\text { Interval of the } \\
\text { Difference }\end{array}$} & & & \\
\hline & & & & Lower & Upper & & & \\
\hline $\begin{array}{ll}\text { Pair } & \text { pretest } \\
1 & \text { postest }\end{array}$ & $\begin{array}{r}7,5294 \\
1\end{array}$ & 6,84564 & 1,17402 & 9,91797 & $-5,14086$ & 6,413 & 33 & .000 \\
\hline
\end{tabular}

\section{Pembahasan Aspek Konteks}

Aspek Context (konteks) program diklat diantaranya yaitu dasar hukum program diklat Diklat Teknis Substantif UN Mata Pelajaran Bahasa Inggris MA di Pusdiklat Tenaga Teknis Pendidikan dan Keagamaan dan tujuan serta sasaran program Diklat Teknis Substantif UN Mata Pelajaran Bahasa Inggris MA di Pusdiklat Tenaga Teknis Pendidikan dan Keagamaan.

Penyelenggaraan program diklat berdasarkan peraturan pemerintah. Dasar penyelenggaraan diklat tersebut terdapat dalam Peraturan Menteri Agama Nomor 75 Tahun 2015 tentang Penyelenggaraan Pendidikan dan Pelatihan Pegawai Pada Kementerian Agama dan Surat Keputusan Kepala Badan Litbang dan Diklat Nomor 62 Tahun 2018 tentang Kurikulum Diklat Teknis
Pendidikan dan Keagamaan. Untuk mencapai efektifitas dan efisiensi, diadakan pengaturan pendidikan serta pengaturan dan penyelenggaraan latihan jabatan ASN yang bertujuan untuk meningkatkan pengabdian, mutu, keahlian, kemampuan dan keterampilan (UU Nomor 52014 tentang ASN). Evaluasi konteks mengenai dasar hukum pada diklat ini telah memenuhi persyaratan yang ada pada peraturan pemerintah tentang pelaksanaan diklat teknis substantif UN Mata Pelajaran Bahasa Inggris MA.

\section{Tujuan dan Sasaran Diklat}

Tujuan dan sasaran harus tertulis jelas agar dapat mengukur keberhasilan program dan menghindarkan ketidakpastian akan program. Hasil evaluasi konteks selayaknya menyediakan dasar yang kuat untuk 
menyesuaikan tujuan yang ada dan prioritas dan menargetkan perubahan yang diperlukan (George F Madaus, dkk 1986: 128). Evaluasi konteks tujuan dan sasaran program diklat UN Mata Pelajaran Bahasa Inggris MA tahun 2018 yaitu minat peserta yang tinggi terhadap diklat sehingga telah memenuhi tujuan dan sasaran program diklat. Penyelenggara diklat telah menganalisis atau melakukan pemilihan sasaran (peserta) diklat yang benar-benar sesuai/relevan dengan tujuan yang hendak dicapai. Hasil Aspek Input program diklat diantaranya yaitu kurikulum diklat, latar belakang sumber daya manusia dan sarana prasarana program Teknis Substantif UN Mata Pelajaran Bahasa Inggris MA.

Struktur kurikulum diklat Teknis Substantif UN Mata Pelajaran Bahasa Inggris MA di Pusdiklat Tenaga Teknis Pendidikan dan Keagamaan antara lain terdiri dari materimateri pelatihan, garis besar program pembelajaran, waktu pelatihan, dan lain-lain. Evaluasi terhadap hal-hal seperti sumber daya manusia dan keuangan, buku panduan dan perlengkapannya, bahan pelajaran, catatan perilaku peserta diklat, efektivitas narasumber, karakteristik lembaga, kondisi program pendidikan. Masukan (input) memberikan informasi tentang bagaimana untuk mencapai tujuan. Catatan penting lainnya adalah kurikulum Diklat Program Diklat Teknis Substantif UN Mata Pelajaran Bahasa Inggris MA di Pusdiklat Tenaga Teknis Pendidikan dan Keagamaan tahun 2018 telah dikaji dan direncanakan kembali secara berkesinambungan, serta adanya penyesuaian/ penambahan materi yang sifatnya mengarah ke pengembangan ilmu pengetahuan yang terbaru dan terkini sesuai dengan perkembangan zaman. Hal ini sesuai dengan salah satu penelitian Deni Setiawan (2016) menyatakan bahwa aspek kurikulum Diklat Program Diklat Teknis Substantif UN Mata Pelajaran Bahasa Inggris MA di Pusdiklat Tenaga Teknis Pendidikan dan Keagamaan tahun 2018 sudah relevan dengan kebutuhan dan tujuan diklat.

Sumber daya manusia yang berperan dalam pelaksanaan diklat Program Diklat Teknis Substantif UN Mata Pelajaran Bahasa Inggris MA di Pusdiklat Tenaga Teknis Pendidikan dan Keagamaan tahun 2018, panitia penyelenggara, pengajar, dan peserta. Stufflebeam (2016b) menyatakan perlu dipertimbangkan apakah sumber daya yang ada dapat dialokasikan atau diperlukan sumber daya tambahan. Sekali lagi, penekanannya pada pengumpulan informasi yang akan digunakan oleh pengambil keputusan.

Evaluasi aspek input sumber daya manusia diklat yaitu penyelenggara diklat telah melakukan analisis tingkat kebutuhan peserta akan diklat sesuai dengan minat peserta. Tenaga pengajar diklat yang berasal dari widyaiswara internal sudah memenuhi kualifikasi sebagai pemberi materi diklat, tetapi sebagian peserta yang mengikuti diklat belum memenuhi persyaratan yang ditentukan panitia penyelenggara sesuai dengan kebutuhan dan tujuan diklat, yaitu masih ada guru Bahasa Inggris MA yang menjadi peserta diklat tidak mengampu kelas XII.

\section{Sarana Prasarana Diklat}

Fasilitas pembelajaran diklat terdiri dari sarana dan prasarana. Sarana diklat terdiri dari alat pelajaran dan media pembelajaran seperti meja, kursi, gedung, laptop, viewers, screen, papan tulis, dan kertas plano untuk simulasi. Sedangkan prasarana diklat antara lain ruang kelas, ruang perpustakaan, ruang kantor, aula, kamar kecil, dan ruang makan. Menurut Stufflebeam (Roger Kaufman \& Susan Thomas, 1980) menyatakan evaluasi masukan (input) berguna untuk mengidentifikasi apa yang sebenarnya diperlukan untuk memenuhi tujuan yang telah ditetapkan dalam evaluasi konteks. Seputar keputusan akan persoalan (isu) mengenai bagaimana membuat struktur program pelajaran yang terbaik dari sumber daya untuk memperoleh tujuan program yang terarah.

Evaluasi aspek input sarana prasarana diklat bahwa sarana prasarana yang tersedia belum mampu menunjang terselenggaranya diklat Teknis Substantif UN Mata Pelajaran Bahasa Inggris MA. Hal demikian akan mengganggu efektifitas kegiatan pembelajaran, sehingga diperlukan perencanaan jumlah dan jenis sarana prasarana sesuai dengan kebutuhan diklat Teknis Substantif UN Mata Pelajaran Bahasa Inggris MA. 
Pembahasan Aspek Process

Aspek process (proses) program diklat diantaranya yaitu media dan metode pembelajaran, serta pelaksanaan program diklat.

\section{Media dan Metode}

Media pembelajaran yang digunakan dalam diklat antara lain LCD, laptop, sound system/wireless mic, whiteboard, spidol warna, modul makanan dan handout. Sedangkan, pendekatan pembelajaran yang digunakan pengajar adalah andragogi (pembelajaran bagi orang dewasa) dengan ragam metode diantaranya ceramah, tanya jawab, latihan soal, simulasi, dan diskusi secara kelompok (studi kasus), dan praktik lapangan.

Stufflebeam (2016c) mengungkapkan program yang akan disampaikan berguna dalam menentukan apakah program ini yang disampaikan seperti yang awalnya direncanakan. Lebih lanjut dijelaskan Proses evaluasi bertujuan untuk menilai secara berkala sejauh mana peserta program menerima dan mampu menjalankan peran mereka (George F. Madaus et al., 1986).

Evaluasi proses mengenai media dan metode pembelajaran diklat yaitu media pembelajaran yang digunakan sepenuhnya menunjang terselenggaranya diklat. Metode mengajar yang diterapkan pengajar telah dijalankan sesuai dengan yang direncanakan penyelenggara diklat. Kegiatan pembelajaraan diklat dilaksanakan sesuai jadwal selama 100 jam pelatihan atau 10 hari. Jadwal pelaksanaan diklat disusun 11 hari yaitu dimulai dari 22 Juli sampai 1 Agustus 2018. Pembagian jadwal mengajar tercantum di dalam jadwal diklat. Menurut Stufflebeam (Roger Kaufman \& Susan Thomas, 1980b), salah satu tujuan proses evaluasi adalah untuk memberikan umpan balik kepada manajer dan staf tentang sejauh mana program kegiatan sesuai jadwal, apakah yang sedang dilaksanakan seperti yang direncanakan, dan apakah menggunakan sumber daya yang tersedia secara efisien.

\section{Pembahasan Aspek Proses}

Program Diklat ini sudah dilaksanakan sesuai dengan jadwal diklat, tetapi materi diklat belum tersampaikan secara maksimal sehingga perlu penambahan waktu diklat. Aspek product (hasil) program diklat diantaranya yaitu kuantitas lulusan dan kualitas peserta diklat.

\section{Kuantitas Peserta}

Evaluasi aspek produk mengenai kuantitas peserta yaitu jumlah lulusan untuk ujian telah memenuhi target lulusan karena jumlah peserta yang mengikuti diklat sebanyak 34 orang semua memperoleh predikat lulus. Hal ini sesuai dengan kriteria yang ditentukan dalam pedoman diklat kualifikasi kelulusan peserta yang ditetapkan dalam panduan: Sangat Kompeten $\quad(92,00<\mathrm{NA}<100)$; Kompeten $\quad(84,00 \quad<N A \quad<92,00)$; Cukup Kompeten $(76,00<$ NA $<84,00)$; dan Kurang Kompeten (NA <76,00). Kelulusan peserta diklat telah berjalan dengan efektif jika dilihat dari hasil diklat.

\section{Kualitas Peserta}

Evaluasi aspek produk mengenai kualitas lulusan yang mengikuti Diklat Teknis Substantif UN Mata Pelajaran Bahasa Inggris MA di Pusdiklat Tenaga Teknis Pendidikan dan Keagamaan tahun 2018 yaitu kualitas lulusan dari diklat dilihat dari meningkatnya kompetensi pengetahuan yang dibuktikan dengan peningkatan hasil nilai pre test dan post test sebesar rata-rata 7,91 (tujuh koma sembilan puluh satu) yang dibuktikan dengan uji t.

\section{PENUTUP}

Secara umum Evaluasi Model CIPP Pada Implementasi program Diklat Teknis Substantif UN Bahasa Inggris MA Pusdiklat Tenaga Teknis Pendidikan dan Keagamaan tahun 2018 telah berjalan dengan baik (sistematik, terencana, teratur, dan berkesinambungan), baik pada tahap context, input, process maupun product.

Aspek Evaluasi context (konteks) menunjukkan bahwa Pusdiklat Tenaga Teknis Pendidikan dan Keagamaan telah memenuhi persyaratan yang ada pada regulasi pelaksanaan diklat. Minat peserta yang tinggi terhadap diklat sehingga memenuhi tujuan dan sasaran program diklat. 
Evaluasi input (masukan) menunjukkan bahwa kurikulum sudah relevan dengan kebutuhan dan tujuan diklat. Sumber daya manusia diklat yaitu penyelenggara diklat telah melakukan analisis tingkat kebutuhan peserta sesuai dengan minat peserta, tenaga widyaiswara sudah memenuhi kualifikasi sebagai pemberi materi diklat, peserta yang mengikuti diklat telah memenuhi persyaratan yang ditentukan panitia penyelenggara sesuai dengan kebutuhan dan tujuan diklat. Sarana prasarana diklat Program Diklat Teknis Substantif UN Mata Pelajaran Bahasa Inggris MA tahun 2018 yang tersedia di Pusdiklat Tenaga Teknis Pendidikan dan Keagamaan sudah mampu menunjang terselenggaranya diklat.

Apsek evaluasi process (proses) Program Diklat ini menunjukkan bahwa media pembelajaran yang digunakan menunjang terselenggaranya diklat. Metode mengajar yang diterapkan widyaiswara dijalankan sesuai dengan yang direncanakan, sudah dilaksanakan sesuai dengan jadwal diklat, namun masih ada materi diklat belum tersampaikan secara maksimal sehingga perlu penambahan waktu diklat.

Aspek evaluasi product (hasil) program diklat, Kuantitas lulusan telah memenuhi target yaitu 33 orang dengan predikat memuaskan dan 1 orang predikat cukup memuaskan dengan tertinggi 87,285 dan nilai terendah 80,75 . Kualitas peserta, terdapat kenaikan ratarata sebesar 7,91 (tujuh koma sembilan puluh satu) yang dibuktikan dengan uji t. Disamping itu peserta mampu menyusun paket soal UN Bahasa Inggris MA dan mempraktikkannya di hadapan peserta didik. Peserta juga telah melakukan tindak lanjut di daerahnya masingmasing, sehingga diklat Teknis Substantif UN Mata Pelajaran Bahasa Inggris MA di Pusdiklat Tenaga Teknis Pendidikan dan Keagamaan tahun 2018 dari aspek dapat dinyatakan efektif.

Berdasarkan kesimpulan maka rekomendasi peneliti adalah diklat Teknis Substantif UN Mata Pelajaran Bahasa Inggris MA dapat dilanjutkan dengan beberapa penyempurnaan. Pertama, meskipun pada aspek konteks, Pusdiklat Tenaga Teknis Pendidikan dan Keagamaan telah memenuhi persyaratan yang ada pada regulasi pelaksanaan diklat dan minat peserta yang tinggi terhadap diklat sehingga memenuhi tujuan dan sasaran program diklat, namun demikian penyelenggara diklat perlu menganalisis atau melakukan pemilihan sasaran (peserta) diklat yang benar-benar memenuhi persyaratan dikarenakan kuota peserta yang terbatas. Pusdiklat perlu melakukan perbaikan untuk pengaturan dan penataan calon peserta diklat unggulan UN yang lebih rinci, di antaranya adalah guru yang mengikuti diklat haruslah guru yang mengajar pada kelas akhir. Tindak lanjut hal lain yang perlu adalah maksimalisasi database narasumber yang pernah mengajar dan memiliki ketepatan spesialisasi serta pengalaman yang mumpuni di bidangnya serta memperoleh feedback positif baik dari peserta, sehingga mutu SDM narasumber bisa tetap dipertahankan.

Kedua, aspek input Pusdiklat Tenaga Teknis Pendidikan dan Keagamaan telah melakukan analisis kebutuhan diklat dan kurikulum telah disusun sesuai namun perlu review atau modifikasi kurikulum diklat UN sebagai diklat unggulan tahun 2018 sesuai dengan perkembangan regulasi yang berkaitan kurikulum dan tuntutan kebutuhan guru. Pola pelatihan in the job training-on the job learning- in the job training (in-on-in) bisa diimplementasikan agar dapat memaksimalkan hasil pelatihan. Ketiga, aspek proses telah memperlihatkan kemampuan para widyaiswara dalam menggunakan media pembelajaran yang disediakan dan melakukan pendekatan andragogi dengan ragam metode interaktif. Namun demikian dalam menghadapi era teknologi dan komunikasi perlu optimalisasi pemanfaatan TIK dalam pembelajaran, misalnya melalui blended learning activities melalui tatap muka dan e-learning.

Keempat, aspek produk Pusdiklat Tenaga Teknis Pendidikan dan Keagamaan perlu melakukan monitoring dan pembinaan berkelanjutan terhadap peserta untuk mengetahui berbagai macam persoalan dalam implementasi materi diklat yang telah diajarkan. 


\section{DAFTAR PUSTAKA}

Arikunto, Suharsimi. 2005. Prosedur Penelitian Suatu Pendekatan Praktik, Jakarta: Renika Cipta

Arikunto, Suharsimi dan Cepi Safrudin Abdul Jabar, 2009, Evaluasi Program Pendidikan, Jakarta: Bumi Aksara

Athiyah, Cut N. Ummu. (2016). Upaya Peningkatan Kualitas Diklat Teknis Melalui Kegiatan Penjaminan Mutu pada 12 (Dua Belas) Balai Diklat Keagamaan. Jurnal Andragogi Pusdiklat Tenaga Teknis Keagamaan, 4(1):45-54

Gomez-Mejia, Luis, David B.Balkin, dan Robert L.Cardy,2001. Managing Human Resources. Englewood Cliffs: PrenticeHall International, Inc.

Gronlund, N. dan Linn,R.L. 1990. Measurement and Evaluation in Teaching 6th edition. New York: Mac Millan Publishing Co.

Peraturan Menteri Agama Nomor 75 Tahun 2015 tentang Penyelenggaraan Pendidikan dan Pelatihan Pegawai pada Kementerian Agama.

Roger Kaufman dan Susan Thomas,1980, Evaluation without Fear. New York: New Viewpointsre

L. Stufflebeam, Daniel. 1971. Educational Evaluation \& Decision Making.. . Itasca, Ill:Peackock.

L. Stufflebeam, Daniel. 2016. Factors That Influenced My Conduct of Evaluations and Evaluation Training Programs: Factors That Influenced My Conduct of Evaluations. New Directions for Evaluation. 2016.. 10.1002/ev.20188.

L. Stufflebeam, Daniel. 2003. "The CIPP Model or Evaluation," makalah disampaikan pada Annual Conference of the Oregon Program Evaluators Network (OPEN), 10 Maret 2003.
Madaus, George. 1985. Test Scores as Administrative mechanism in Education Policy.Phi Delta Kappan.

Setiawan, Deni. 2016. "Pengembangan Kurikulum Pendidikan berbasisi KKNI dan Berwawasan Kebangsaan Sebagai Program Dukungan Pembangunan Berkelanjutan di Bidang Pendidikan" http://ojs.unm.ac.id/PSN

HSIS/article/download/2760/1501(diund uh tanggal 28 Desember 2018 ).

Sukarna. 2011. Dasar-Dasar Manajemen. CV. Mandar Maju. Bandung.

Suprabowo, Eko Rachmat. 2012. Evaluasi program pelatihan komputer di Balai Latihan Kerja Kabupaten Kulon Progo. Skripsi:diakses tanggal 22 Januari 2018 melalui eprints.uny.ac.id/26914/1/Eko\%20Rach mat\%20Suprabowo.

Suprayogo,Imam dan Tobroni. 2001. Metodologi Penelitian Sosial-Agama. Remaja Rosda Karya. Bandung.

Tri Widodo, Wahyu.2012. Evaluasi Program Pendidikan Dan Pelatihan Operator Komputer Di Balai Latihan Kerja Siraman Wonosari Gunungkidul. Skripsi: diakses tanggal 22 Januari 2018 melalui http://eprints.uny.ac.id/6197/1/Abstrak\% 20Wahyu\% 20Tri\%20Widodo.

Undang-undang Nomor 20 Tahun 2003 tentang Sistem Pendidikan Nasional.

Undang-undang Nomor 5 Tahun 2014 tentang Aparatur Sipil Negara.

Peraturan Pemerintah Nomor 101 Tahun 2004 tentang Pendidikan dan Pelatihan Jabatan Pegawai Negeri Sipil. 